\title{
FAKTOR-FAKTOR YANG BERHUBUNGAN DENGAN KEMISKINAN DI DESA JATI MULYO KECAMATAN JATI AGUNG KABUPATEN LAMPUNG SELATAN
}

\author{
(Factors Related to Poverty in Jati Mulyo Village Jati Agung District South Lampung Regency)
}

Sasmita Padena Harahap, Kordiyana K. Rangga, Yuniar Aviati Syarief

Jurusan Agribisnis, Fakultas Pertanian, Universitas Lampung, J1. Prof. Dr. Soemantri Brojonegoro No. 1

Bandar Lampung 35145, e-mail: kordiyana.rangga@fp.unila.ac.id

\begin{abstract}
This research aims to determine poverty level, and factor related to the poverty level in Jati Mulyo Village, Jati Agung District, South Lampung Regency. This research was conducted in March-April 2018. Respondents were 70 households of poor families. Data were collected with a survey method using quantitative descriptive analysis and nonparametric statistical test (rank Spearman correlation). Results of this research showed that annual expenditure per capita was equivalent to the value of 233 kilograms of rice or the households were included in very poor category. Factors that were significantly related to poverty level were level of education and main occupation, while the number of family members and the age of the head of the household were not significantly related to poverty level.
\end{abstract}

Key words: household, poor, poverty level

\section{PENDAHULUAN}

Salah satu tujuan pembangunan nasional adalah meningkatkan kinerja perekonomian, agar mampu menciptakan lapangan kerja dan menata kehidupan yang layak bagi seluruh rakyat untuk mewujudkan kesejahteraan penduduk Indonesia. Salah satu sasaran pembangunan nasional adalah menurunkan tingkat kemiskinan. Upaya pengentasan kemiskinan harus dilakukan secara komprehensif, mencakup berbagai aspek kehidupan masyarakat, dan dilaksanakan secara terpadu.

Kemiskinan merupakan masalah global, sering dihubungkan dengan kebutuhan, kesulitan dan kekurangan diberbagai keadaan hidup. Tingginya tingkat kemiskinan di beberapa provinsi yang ada di Indonesia memberi gambaran bahwa masalah kemiskinan masih menjadi masalah utama yang harus segera diatasi pemerintah, khususnya pemerintah daerah terutama setelah otonomi daerah diberlakukan.

Menurut Badan Pusat Statistik Kabupaten Lampung Selatan (2018), jumlah penduduk miskin untuk Kabupaten Lampung Selatan menempati peringkat teratas pada tahun 2018 sebanyak 148.530 jiwa. Menurut Badan Kependudukan dan Keluarga Berencana Nasional Provinsi Lampung (2006), jumlah penduduk prasejahtera Provinsi Lampung pada tahun 2018 tertinggi berada di Kecamatan Jati Agung Kabupaten Lampung Selatan, dengan jumlah keluarga prasejahtera sebanyak 5.794 jiwa. Desa Jati Mulyo Kecamatan Jati Agung Kabupaten Lampung Selatan mempunyai 21 desa dengan jumlah penduduk prasejahtera sebanyak 753 jiwa. Sehubungan dengan hal tersebut, maka perlu dilakukan penelitian dengan tujuan mengetahui tingkat kemiskinan di Desa Jati Mulyo, Kecamatan Jati Agung, Kabupaten Lampung Selatan dan mengetahui faktor-faktor yang berhubungan dengan tingkat kemiskinan.

\section{METODE PENELITIAN}

Penetapan lokasi penelitian ini dipilih dengan pertimbangan bahwa Desa Jati Mulyo mempunyai jumlah penduduk prasejahtera menempati urutan kedua sebanyak 753 jiwa setelah Desa Karang Anyar dengan jumlah penduduk prasejahtera sebanyak 818 jiwa. Metode yang digunakan dalam penelitian ini adalah metode survei dan dilakukan pada bulan Maret-April 2018. Data yang digunakan pada penelitian ini adalah data primer dan data sekunder.

Data primer didapat dari hasil wawancara dengan menggunakan kuisioner, sedangkan data sekunder diperoleh dari studi pustaka/literatur, dan data-data yang didapat dari lembaga-lembaga yang terkait dengan penelitian ini seperti Badan Kependudukan Keluarga Berencana Nasional Provinsi Lampung, Badan Pusat Statistik Kabupaten Lampung Selatan, Badan Pusat Statistik Provinsi Lampung, serta monografi desa. Responden data penelitian adalah 
rumah tangga prasejahtera dipilih menggunakan proportional random sampling. Penentuan jumlah sampel menggunakan rumus Sugiarto, Sunaryanto dan Oetomo (2003) dengan rumus sebagai berikut:

$\mathrm{n}=1 \frac{\mathrm{NZ}^{2} \mathrm{~S}^{2}}{\mathrm{Nd}^{2}+\mathrm{Z}^{2} \mathrm{~S}^{2}}$

Keterangan :

$\mathrm{n} \quad=$ Jumlah sampel

$\mathrm{N} \quad=$ Jumlah rumah tangga prasejahtera (753 jiwa)

$\mathrm{Z}=$ Tingkat kepercayaan $(95 \%=1,96)$

$\mathrm{S}^{2} \quad=$ Variasi sampel $(5 \%=0,05)$

$\mathrm{d}=$ Derajat penyimpangan $(5 \%=0,05)$

Berdasarkan perhitungan dengan menggunakan rumus di atas, diperoleh jumlah unit sampel untuk penduduk miskin di Desa Jati Mulyo adalah 70 jiwa. Metode analisis untuk mengukur tingkat kemiskinan rumah tangga prasejahtera menggunakan kriteria tingkat kemiskinan Sayogyo (1997), yaitu dengan pendekatan pengeluaran rumah tangga. Perhitungan ini dilakukan dengan cara menghitung pengeluaran per kapita per tahun. Total pengeluaran rumah tangga dapat dihitung dengan menggunakan rumus:

$\mathrm{Ct}=\mathrm{Ca}+\mathrm{Cb}$

Keterangan:

$\mathrm{Ct}=$ Total pengeluran rumah tangga $(\mathrm{Rp})$

$\mathrm{Ca} \quad=$ Pengeluaran untuk pangan $(\mathrm{Rp})$

$\mathrm{Cb} \quad=$ Pengeluaran untuk nonpangan $(\mathrm{Rp})$

Menurut Sayogyo (1997), pengeluaran rumah tangga per kapita per tahun adalah total pengeluaran rumah tangga untuk pangan maupun nonpangan dalam setahun dibagi jumlah anggota keluarga, selanjutnya dikonversikan ke dalam ukuran setara beras per kilogram, agar dapat diketahui tingkat kemiskinannya. Ukuran setara beras per kilogram menggunakan harga beras sebesar Rp10.389,00/kg (Badan Pusat Statistik Kabupaten Lampung Selatan 2018). Penentuan tingkat pengeluaran per kapita per tahun pada rumah tangga dan tingkat pengeluaran per kapita per tahun setara beras menggunakan pendekatan kriteria Sayogyo (1997).

Klasifikasi tingkat kemiskinan menurut Sayogyo (1997) digolongkan ke dalam tiga bagian yaitu:

a. Paling miskin adalah jika pengeluaran anggota keluarga adalah $<180,00 \mathrm{~kg}$ setara beras/tahun. b. Miskin sekali adalah jika pengeluaran anggota keluarga adalah $181,00-240,00 \mathrm{~kg}$ setara beras/tahun.

c. Miskin adalah jika pengeluaran anggota keluarga adalah $241,00-320,00 \mathrm{~kg}$ setara beras/tahun.

Metode analisis data adalah metode deskriptif kuantitatif untuk menjawab tujuan pertama, dan menjawab tujuan kedua menggunakan analisis statistik nonparametrik korelasi Rank Spearman dengan SPSS 24 (Statistical Programs for Sosial Science). Uji korelasi Rank Spearman digunakan untuk melihat hubungan antara variabel $\mathrm{X}$ dan $\mathrm{Y}$ atau digunakan untuk menguji signifikansi hipotesis masing-masing variabel. Rumus uji koefisien korelasi Rank Spearman (Siegel 1997) adalah sebagai berikut:

$r_{s}=1-\frac{6 \sum_{\mathrm{i}-1}^{\mathrm{n}} \mathrm{di}^{2}}{\mathrm{n}^{3}}$

Keterangan:

$r_{s} \quad=$ Koefisien korelasi

di $\quad=$ Perbedaan setiap pasangan rankl peringkat

$\mathrm{n} \quad=$ Jumlah responden

Kaidah pengambilan keputusan adalah sebagai berikut:

1. Jika nilai signifikansi $\leq(\alpha)=0,05$ atau $(\alpha)=$ 0,01 maka terima $\mathrm{H}_{1}$, berarti terdapat hubungan antara kedua variabel yang diuji.

2. Jika nilai signifikansi $>(\alpha)=0,05$ atau $(\alpha)=$ 0,01 maka tolak $H_{1}$, berarti tidak terdapat hubungan antara kedua variabel yang diuji.

\section{HASIL DAN PEMBAHASAN}

\section{Karakteristik Responden}

Jumlah responden sebanyak 70 jiwa rumah tangga prasejahtera di Desa Jatimulyo. Tabel 1 menunjukkan bahwa sebagian besar tingkat pendidikan rumah tangga prasejahtera di Desa Jati Mulyo masih tergolong rendah yaitu jenjang SD sebanyak 33 jiwa dengan persentase sebanyak 47,14 persen. Tingkat pendidikan akan mempengaruhi seseorang dalam menyikapi sesuatu hal yang baru. Tingkat pendidikan rumah tangga prasejahtera yang memiliki jenjang pendidikan lebih tinggi tentunya akan lebih mudah dalam memperoleh informasi serta mampu menerapkan teknologi yang diterima dibandingkan rumah tangga prasejahtera yang berpendidikan rendah. 
Tabel 1. Identitas responden di Desa Jati Mulyo Kecamatan Jati Agung tahun 2018

\begin{tabular}{|c|c|c|c|c|}
\hline No. & Variabel & Klasifikasi & Responden (Jiwa) & Persentase $(\%)$ \\
\hline \multirow{4}{*}{1.} & \multirow{4}{*}{ Tingkat Pendidikan } & SD & 33 & 47,14 \\
\hline & & SMP & 14 & 20,00 \\
\hline & & SMA & 23 & 32,86 \\
\hline & & & Jumlah & 100,00 \\
\hline \multirow{7}{*}{2.} & \multirow{7}{*}{ Pekerjaan Utama } & On Farm (Petani Padi Sawah) & 26 & 37,14 \\
\hline & & Off Farm (Buruh Tani) & 16 & 22,86 \\
\hline & & Non Farm: & & \\
\hline & & a) Buruh Bangunan & 13 & 18,57 \\
\hline & & b) Pedagang & 8 & 11,43 \\
\hline & & c) Karyawan Swasta & 7 & 10,00 \\
\hline & & & Jumlah & 100,00 \\
\hline \multirow{4}{*}{3.} & \multirow{4}{*}{$\begin{array}{l}\text { Jumlah Anggota } \\
\text { Keluarga }\end{array}$} & $3,00-4,00$ & 20 & 28,57 \\
\hline & & $5,00-6,00$ & 50 & 71,43 \\
\hline & & $7,00-8,00$ & 0 & 0,00 \\
\hline & & & Jumlah & 100,00 \\
\hline \multirow{4}{*}{4.} & \multirow{4}{*}{$\begin{array}{l}\text { Usia Kepala Rumah } \\
\text { Tangga }\end{array}$} & $0,00-14,00$ & 0 & 0,00 \\
\hline & & $15,00-64,00$ & 70 & 100,00 \\
\hline & & $>65,00$ & 0 & 0,00 \\
\hline & & & Jumlah & 100,00 \\
\hline \multirow{3}{*}{5.} & \multirow{3}{*}{ Pekerjaan Sampingan } & Buruh & 3 & 60,00 \\
\hline & & Pedagang & 2 & 40,00 \\
\hline & & & Jumlah & 100,00 \\
\hline
\end{tabular}

Pekerjaan utama rumah tangga prasejahtera sebagian besar bekerja sebagai petani padi sawah sebanyak 26 jiwa dengan persentase sebesar 37,14 persen. Rumah tangga prasejahtera di Desa Jati Mulyo masih mengandalkan pertanian sebagai sumber pendapatan utama mereka. Kegiatan ekonomi di perdesaan masih tetap menempatkan sektor pertanian sebagai sektor yang memegang peranan penting, baik dalam menyerap tenaga kerja maupun dalam menyumbang pendapatan. Pendapatan yang diterima rumah tangga prasejahtera dari berbagai sumber diharapkan mampu memenuhi kebutuhan rumah tangganya.

Jumlah anggota keluarga rumah tangga prasejahtera sebanyak lima sampai enam orang dengan persentase sebesar 71,43 persen. Jumlah anggota keluarga akan mempengaruhi tingkat pengeluaran rumah tangga, baik pengeluaran pangan maupun pengeluaran nonpangan. Banyaknya jumlah anggota keluarga yang ditanggung kepala keluarga menjadi beban serta pendapatan yang dikeluarkan pun semakin besar. Usia kepala rumah tangga prasejahtera memiliki usia produktif sebanyak 70 jiwa dengan persentase sebanyak 100 persen. Rata-rata usia kepala rumah tangga rumah tangga prasejahtera yaitu 41 tahun. Rumah tangga prasejahtera dengan umur produktif akan lebih mudah dalam mengelola risiko lingkungan, sedangkan rumah tangga prasejahtera yang usianya sudah tidak produktif lagi memiliki keterbatasan fisik dan cenderung netral ataupun menghindari risiko lingkungan dalam menjalankan pekerjaan.

Pekerjaan sampingan yang dilakukan oleh rumah tangga prasejahtera sebagai buruh tani sebanyak 3 jiwa dengan persentase sebesar 60 persen. Pekerjaan sampingan dilakukan oleh rumah tangga prasejahtera untuk menambah penghasilan di luar dari penghasilan pokok dalam bekerja. Pekerjaan sampingan dapat berupa pekerjaan tetap atau tidak tetap. Pekerjaan tetap seperti berdagang, sedangkan pekerjaan tidak tetap seperti buruh di luar pertanian. Hal tersebut dilakukan agar rumah tangga prasejahtera mendapatkan tambahan pendapatan untuk memenuhi kebutuhan yang diperlukan. Rumah tangga prasejahtera yang menjadi buruh tani dilakukan di luar musim tanam.

Petani yang bekerja sebagai buruh tani pada waktu menunggu lahan untuk siap kembali ditanam, pada akhir masa panen hingga menunggu untuk musim tanam selanjutnya atau saat tanaman tidak memerlukan perawatan yang intensif oleh petani padi sawah. 
Tabel 2. Rata-rata pengeluaran rumah tangga per kapita per tahun prasejahtera di Desa Jati Mulyo Kecamatan Jati Agung Kabupaten Lampung Selatan tahun 2018

\begin{tabular}{|c|c|c|c|c|}
\hline No. & $\begin{array}{c}\text { Jenis } \\
\text { Pengeluaran }\end{array}$ & $\begin{array}{l}\text { Macam-macam } \\
\text { Pengeluaran }\end{array}$ & $\begin{array}{c}\text { Rata-rata Pengeluaran Rumah } \\
\text { Tangga/Kapita/Tahun }\end{array}$ & Persentase $(\%)$ \\
\hline \multirow[t]{13}{*}{1.} & Pangan & Padi-padian & $163.330,00$ & 28,04 \\
\hline & & Umbi-umbian & $17.557,14$ & 3,01 \\
\hline & & Hewani & $38.814,29$ & 6,66 \\
\hline & & Minyak dan Lemak & $25.428,57$ & 4,37 \\
\hline & & Buah dan Biji Berminyak & $18.828,57$ & 3,23 \\
\hline & & Kacang-kacangan & $22.442,85$ & 3,85 \\
\hline & & Gula & $34.442,86$ & 5,91 \\
\hline & & Sayur dan Buah & $89.200,00$ & 15,32 \\
\hline & & Rokok & $33.142,93$ & 5,69 \\
\hline & & Bumbu & $98.750,00$ & 16,96 \\
\hline & & Lain-lain & $40.471,43$ & 6,95 \\
\hline & & Pengeluaran Pangan/bulan & $582.408,64$ & 100,00 \\
\hline & & Pengeluaran Pangan/tahun & $6.988 .903,68$ & 61,99 \\
\hline \multirow[t]{15}{*}{2.} & Nonpangan & Kesehatan & $5.614,29$ & 1,57 \\
\hline & & Pendidikan & $1.928,57$ & 0,54 \\
\hline & & Listrik & $74.785,71$ & 20,94 \\
\hline & & Telp/Hp & $19.071,43$ & 5,34 \\
\hline & & Perabotan Rumah & $1.264,29$ & 0,35 \\
\hline & & Aksesoris & 0,00 & 0,00 \\
\hline & & Barang dan Jasa & 0,00 & 0,00 \\
\hline & & Bahan Bakar & $180.200,00$ & 50,45 \\
\hline & & Transportasi & $3.882,35$ & 1,09 \\
\hline & & Sosial & $9.000,00$ & 2,52 \\
\hline & & Kebersihan badan & $58.578,57$ & 16,40 \\
\hline & & Lain-lain & $2.857,14$ & 0,80 \\
\hline & & Pengeluaran Nonpangan/bulan & $357.182,35$ & 100,00 \\
\hline & & Pengeluaran Nonpangan/tahun & $4.286 .188,20$ & 38,01 \\
\hline & & $\begin{array}{l}\text { Total Pengeluaran Pangan dan } \\
\text { Nonpangan/tahun }\end{array}$ & $11.275 .091,90$ & 100,00 \\
\hline
\end{tabular}

Berdasarkan Tabel 2, pengeluaran pangan per kapita per tahun prasejahtera di Desa Jati Mulyo Kecamatan Jati Agung Kabupaten Lampung Selatan lebih besar dari pengeluaran nonpangan. Pada kelompok padi-padian menyumbang paling besar untuk pengeluaran pangan per kapita per tahun. Pengeluaran atas beras lebih besar dibandingkan dengan ketan, jagung, dan tepung terigu. Pola konsumsi bahan pokok pada prinsipnya sama yaitu mereka mengonsumsi beras sebagai makanan pokoknya. Kemudian kelompok bumbu-bumbuan menyumbang pengeluaran pangan per kapita per tahun terbesar kedua setelah kelompok padi-padian. Jenis konsumsi bumbubumbuan yang paling banyak dikonsumsi oleh rumah tangga prasejahtera adalah bawang merah. Bumbu bawang merah banyak digunakan sebagai bumbu pelengkap masakan.

Kelompok sayuran dan buah menyumbang urutan terbesar ketiga untuk pengeluaran pangan per kapita per tahun. Sayuran dan buah sangat penting untuk dikonsumsi, karena kandungan vitamin dan seratnya yang sangat baik bagi kesehatan. Sayur dan buah adalah sumber beberapa mineral dan vitamin yang penting. Sayuran yang berwarna hijau biasanya kaya akan mineral besi serta vitamin A dan C. Semakin gelap warna hijau sayuran, biasanya semakin tinggi kandungan akan zat besi dan vitamin A. Demikian pula buahbuahan yang berwarna kuning sampai merah, kaya akan vitamin A dan C. Pangan tersebut merupakan sumber zat tenaga yang baik, beberapa di antaranya bahkan mengandung mineral dan vitamin yang berguna bagi tubuh.

Sayuran menjadi bahan makanan wajib yang harus dipenuhi oleh rumah tangga prasejahtera. Sayuran yang paling sering dikonsumsi oleh rumah tangga prasejahtera adalah kangkung, daun singkong, dan kacang panjang. Ketiga sayuran tersebut menjadi sayuran yang paling sering dikonsumsi, karena mudah didapat dan harganya yang relatif lebih murah. Jenis konsumsi buah-buahan yang paling 
sering dikonsumsi oleh rumah tangga prasejahtera per kapita per tahun adalah buah pisang dan papaya. Buah ini menjadi buah yang paling sering dikonsumsi, karena mudah didapat dan harganya yang relatif lebih murah.

Jenis konsumsi lain-lain untuk rumah tangga per kapita per tahun prasejahtera adalah minuman jadi dan makanan jadi yang biasa mereka beli diluar dari makanan pokok seperti makanan dan minuman kemasan yang sudah banyak dijual di pasaran. Kemudian untuk pengeluaran pangan per kapita per tahun hewani yaitu ikan segar. Ikan merupakan jenis pangan hewani yang mudah didapat dengan harga yang terjangkau, karena banyaknya penjual ikan di daerah penelitian.

Jenis konsumsi minuman rumah tangga prasejahtera adalah air mineral. Rumah tangga prasejahtera mengonsumsi air mineral dengan cara memasak langsung dari air sumur yang dimiliki, Selain itu, terdapat pula yang mengkonsumsi air isi ulang untuk minuman sehari-harinya. Selain air mineral, minuman yang sering dikonsumsi kopi dan teh, karena untuk menghangatkan tubuh serta penghilang rasa lelah dan kantuk. Jenis konsumsi kacang-kacangan merupakan bahan makanan yang kaya akan protein nabati, sehingga banyak dikonsumsi oleh rumah tangga prasejahtera, karena harga yang relatif murah dan mudah didapatkan.

Jenis konsumsi umbi-umbian menyumbang pengeluaran per kapita per tahun terkecil dari kelompok pengeluran untuk pangan. Umbiumbian seperti ubi jalar, singkong dan kentang yang dikonsumsi oleh rumah tangga prasejahtera. Kandungan protein singkong lebih rendah dibandingkan dengan beras. Umbi-umbian merupakan pangan yang mengandung karbohidrat tinggi dan banyak ditanam, sehingga mudah didapatkan dan harganya relatif murah.

Bahan bakar menyumbang paling besar untuk pengeluaran nonpangan per kapita per tahun. Bahan bakar yang paling banyak digunakan seharihari adalah bensin. Bahan bakar digunakan pada kendaraan bermotor sebagai alat transportasi. Selain bensin yaitu gas dan minyak tanah. Pada rumah tangga prasejahtera, listrik menyumbang terbesar kedua setelah bahan bakar, karena listrik banyak digunakan untuk keperluan sehari-hari seperti handphone, televisi, lampu, dan lain-lain.

Keperluan mandi yang dikeluarkan oleh rumah tangga prasejahtera yaitu sabun mandi, pasta gigi, sikat gigi, shampo, dan lain-lain. Kegiatan sosial yang dilakukan oleh rumah tangga prasejahtera adalah kegiatan menyumbang ketika saudara atau tetangga ada yang menyelenggarakan hajatan dan berduka cita. Pengeluaran keperluan lain-lain oleh rumah tangga prasejahtera seperti keperluan untuk perawatan kendaraan pribadi dan lain sebagainya.

Tingkat kemiskinan rumah tangga diperoleh dari pengeluaran rumah tangga per kapita per tahun. Pengeluaran rumah tangga per kapita per tahun adalah total pengeluaran rumah tangga untuk pangan maupun nonpangan dalam setahun dibagi jumlah anggota keluarga. Total pengeluaran rumah tangga kemudian dikonversikan ke dalam ukuran setara beras per kilogram, untuk mengetahui tingkat kemiskinan rumah tangga. Ukuran setara beras per kilogram menggunakan harga beras sebesar Rp10.389,00/kg (Badan Pusat Statistik Kabupaten Lampung Selatan 2018), untuk melihat tingkat kemiskinan rumah tangga prasejahtera dapat digolongkan ke dalam tiga golongan. Penduduk prasejahtera yang tergolong dalam kategori miskin sekali sebanyak 48 jiwa dengan persentase sebesar 68,97 persen. Tingkat konsumsi beras per kapita per tahun pada suatu rumah tangga mempengaruhi jumlah pengeluaran per kapita per tahun dalam mengkonsumsi beras.

Rata-rata pengeluaran rumah tangga per kapita per tahun di Desa Jati Mulyo setara nilai beras adalah sebesar 233 kilogram nilai beras per tahun. Berdasarkan kriteria yang telah ditetapkan oleh Sayogyo (1997), pengeluaran rumah tangga per kapita per tahun penduduk prasejahtera di Desa Jati Mulyo berada di antara 181-240 kilogram nilai beras per tahun, sehingga sebagian besar penduduk prasejahtera berada pada kriteria miskin sekali sebanyak 48 jiwa dengan persentase sebesar 68,57 persen dapat dilihat pada Tabel 3.

\section{Faktor-faktor yang Berhubungan dengan Kemiskinan}

Faktor-faktor yang berhubungan dengan kemiskinan yaitu tingkat pendidikan dan pekerjaan utama sedangkan jumlah anggota keluarga dan usia kepala rumah tangga tidak berhubungan dengan kemiskinan di Desa Jati Mulyo Kecamatan Jati Agung Kabupaten Lampung Selatan. Pengujian hipotesis dan pembahasan antara faktor-faktor yang berhubungan dan tidak berhubungan dengan tingkat kemiskinan di Desa Jati Mulyo Kecamatan Jati Agung Kabupaten Lampung Selatan dapat dilihat pada Tabel 4. 
Tabel 3. Sebaran rumah tangga prasejahtera berdasarkan tingkat kemiskinan di Desa Jati Mulyo Kecamatan Jati Agung Kabupaten Lampung Selatan tahun 2018

\begin{tabular}{|c|c|c|c|}
\hline Variabel & Klasifikasi & $\begin{array}{c}\text { Jumlah Responden } \\
\text { (Jiwa) }\end{array}$ & $\begin{array}{l}\text { Persentase } \\
(\%)\end{array}$ \\
\hline & Miskin $(241,00-320,00 \mathrm{~kg}$ beras $)$ & 13 & 18,57 \\
\hline Tingkat & Miskin Sekali (181,00-240,00 kg beras) & 48 & 68,57 \\
\hline \multirow[t]{2}{*}{ Kemiskinan } & Paling Miskin $(<180,00 \mathrm{~kg}$ beras $)$ & 9 & 12,86 \\
\hline & & Jumlah & 100,00 \\
\hline
\end{tabular}

Tabel 4 menunjukkan bahwa hasil analisis korelasi Rank Spearman antara variabel X (faktor-faktor yang berhubungan dengan kemiskinan) terhadap variabel Y (Tingkat kemiskinan Sayogyo 1997) di Desa Jati Mulyo Kecamatan Jati Agung Kabupaten Lampung Selatan tahun 2018 yaitu pendidikan sebagai usaha menghasilkan perubahan-perubahan perilaku manusia. Pendidikan adalah suatu proses terencana untuk mengubah perilaku seseorang yang dilandasi adanya perubahan pengetahuan, keterampilan, dan sikapnya. Hakekatnya, pendidikan adalah untuk meningkatkan kemampuan manusia guna mempertahankan dan memperbaiki mutu keberadaannya, agar menjadi semakin baik.

Pendidikan merupakan salah satu modal untuk mempermudah penyerapan informasi maupun menambah pengetahuan. Semakin tinggi pendidikan seseorang, maka akan meningkatkan produktivitas. Peningkatan produktivitas ini akan meningkatkan pendapatan baik pendapatan individu maupun pendapatan nasional. Peningkatan pendapatan individu akan meningkatkan kemampuan konsumsi mereka, sehingga dapat mengangkat kehidupan mereka dari kemiskinan. Hasil penelitian ini sejalan dengan penelitian Utami (2016) yang menyatakan bahwa terdapat hubungan yang nyata antara tingkat pendidikan terhadap kemiskinan.

Pekerjaan atau mata pencaharian dapat diartikan sebagai pekerjaan atau mata pencaharian utama yang dilakukan setiap hari untuk memenuhi kebutuhan, sehingga dapat diartikan bahwa pekerjaan atau mata pencaharian adalah usaha manusia dalam memenuhi kebutuhan hidupnya. Pekerjaan utama rumah tangga prasejahtera di Desa Jati Mulyo terbagi menjadi tiga bagian yaitu sebagai petani padi sawah (on farm), buruh tani (off farm), dan bekerja pada sektor di luar pertanian (non farm).

Mayoritas rumah tangga prasejahtera bekerja sebagai petani dan buruh, sehingga semakin banyak kepala rumah tangga yang bekerja sebagai petani dan buruh, maka akan semakin besar peluang rumah tangga tersebut dalam kemiskinan. Hasil penelitian ini sejalan dengan penelitian Hamdani dan Wulandari (2013) yang menyatakan bahwa terdapat hubungan yang nyata antara pekerjaan terhadap kemiskinan. Jumlah anggota keluarga adalah jumlah anggota keluarga yang menjadi tanggungan keluarga tersebut.

Keluarga didefinisikan sebagai sekumpulan orang yang tinggal dalam satu rumah yang masih mempunyai hubungan kekerabatan/hubungan darah karena perkawinan, kelahiran, adopsi dan lain sebagainya. Terdapat jumlah anggota keluarga rumah tangga prasejahtera yang bekerja, maka dapat membantu perekonomian keluarga seiring dengan kebutuhan hidup yang harus dipenuhi.

Tabel 4. Hasil analisis korelasi Rank Spearman antara variabel X (faktor-faktor yang berhubungan dengan kemiskinan) terhadap variabel Y (Tingkat kemiskinan Sayogyo 1997) di Desa Jati Mulyo Kecamatan Jati Agung Kabupaten Lampung Selatan tahun 2018

\begin{tabular}{lccccc}
\hline \multicolumn{1}{c}{ Variabel X } & Variabel Y & $\begin{array}{l}\text { Koefisien } \\
\text { Korelasi }\left(\mathrm{r}_{\mathrm{s}}\right)\end{array}$ & Sig (2-tailed) & $\alpha$ & Keputusan \\
\hline Tingkat Pendidikan & Tingkat Kemiskinan & $0,367^{* *}$ & 0,002 & 0,05 & $\mathrm{H}_{1}$ diterima \\
Pekerjaan Utama & Tingkat Kemiskinan & $0,250^{*}$ & 0,037 & 0,05 & $\mathrm{H}_{1}$ diterima \\
Jumlah Anggota Keluarga & Tingkat Kemiskinan & 0,017 & 0,888 & 0,05 & $\mathrm{H}_{1}$ ditolak \\
Usia Kepala Rumah Tangga & Tingkat Kemiskinan & 0,221 & 0,066 & 0,05 & $\mathrm{H}_{1}$ ditolak \\
\hline
\end{tabular}


Hasil penelitian ini tidak sejalan dengan penelitian Susilowati (2014) yang menyatakan bahwa terdapat hubungan antara jumlah anggota keluarga dengan kemiskinan. Usia kepala rumah tangga rumah tangga prasejahtera yaitu rata-rata berada pada usia produktif. Kelompok usia produktif secara fisik memiliki potensi yang besar untuk menghasilkan barang dan jasa (Putri dan Nyoman 2013). Hasil penelitian ini tidak sejalan dengan penelitian Susilowati (2014) yang menyatakan bahwa terdapat hubungan yang nyata antara usia kepala rumah tangga dengan kemiskinan.

\section{KESIMPULAN}

Tingkat kemiskinan rumah tangga prasejahtera di Desa Jati Mulyo, Kecamatan Jati Agung, Kabupaten Lampung Selatan termasuk kategori miskin sekali, dilihat dari pengeluaran per kapita per tahun setara nilai beras adalah sebesar 233 kilogram nilai beras per kapita per tahun. Faktorfaktor yang berhubungan nyata dengan tingkat kemiskinan adalah tingkat pendidikan dan pekerjaan utama, sedangkan yang tidak berhubungan nyata adalah jumlah anggota keluarga dan usia kepala rumah tangga.

\section{DAFTAR PUSTAKA}

BKKBN [Badan Kependudukan dan Keluarga Berencana Nasional] Provinsi Lampung. 2006. Indikator Tahapan Keluarga Tahun 2006. BKKBN Provinsi Lampung. Bandar Lampung.

BPS [Badan Pusat Statistik] Kabupaten Lampung Selatan. 2018. Kabupaten Lampung Selatan Dalam Angka 2018. Badan Pusat Statistik Provinsi Lampung. Bandar Lampung.
BPS [Badan Pusat Statistik] Provinsi Lampung. 2018. Lampung dalam Angka 2018. BPS Provinsi Lampung. Bandar Lampung.

BPS [Badan Pusat Statistik] Provinsi Lampung. 2018. Garis Kemiskinan Menurut Provinsi Tahun 2016-2018. BPS Provinsi Lampung. Bandar Lampung.

Hamdani H dan Wulandari K. 2013. Faktor penyebab kemiskinan nelayan tradisional. Artikel Ilmiah Hasil Penelitian Mahasiswa 2013: 1-8. http://repository.unej.ac.id/bitstr eam/handle/123456789/58737/Haris\%20Ham dani.pdf;sequence $=1$. [05 Oktober 2019].

Putri AD dan Nyoman DS. 2013. Pengaruh umur, pendidikan, pekerjaan terhadap pendapatan rumah tangga miskin di Desa Bebandem. EJurnal EP Unud, 2 (4): 173-180. https://ojs.unud.ac.id/index.php/eep/article/ view/4768. [03 Juli 2019].

Sayogyo. 1997. Garis Kemiskinan dan Kebutuhan Minimum Pangan. LPSB IPB. Bogor.

Siegel S. 1997. Statistik Non-Parametrik Ilmu-Ilmu Sosial. PT Gramedia Pustaka Utama. Jakarta.

Sugiarto DS, LT Sunaryanto dan DS Oetomo. 2003. Teknik Sampling. PT Gramedia Pustaka Utama. Jakarta.

Susilowati HH. 2014. Faktor-faktor yang mempengaruhi ketahanan pangan rumah tangga miskin di Kecamatan Srandakan Bantul. Skripsi. Universitas Negeri Yogyakarta. Yogyakarta.

Utami PP. 2016. Pendapatan dan kesejahteraan petani jagung di Kecamatan Ketapang Kabupaten Lampung Selatan. Skripsi. http://digilib.unila.ac.id/22455/. [12 Juni 2019]. 